\title{
Identifying the Economic Effects of Salt Water Intrusion after Hurricane Katrina
}

\author{
Vereda Johnson Williams \\ Economics, Transportation and Logistics Department \\ North Carolina A\&T State University \\ Greensboro, NC 27411, USA \\ Tel: 336-334-7188 ext. 2008 336-256-2055 (fax) E-mail: kingvj@ncat.edu
}

\begin{abstract}
Hurricane Katrina made landfall August 29, 2005 becoming the costliest and one of the deadliest hurricanes in U.S. history. Katrina caused widespread loss of life, with over 700 bodies recovered in New Orleans by October 23, 2005. Before Hurricane Katrina, the region supported approximately one million non-farm jobs, with 600,000 of them in New Orleans. The ecological consequences were considerable including storm surge floods into coastal areas. These ecological impacts are still being felt throughout the region through human-driven coastal erosion and saltwater intrusion - issues that have long been damaging the region's natural storm buffers - were made worse by the hurricane. Specifically this research will: (1) provide current updates of the economic and ecological impacts from Katrina (2) review the current literature relating to salt water intrusion and (3) identify the economic impact of salt water erosion from hurricane Katrina including a specific case.
\end{abstract}

Keywords: Economics, Environment, Ecology, Salt water intrusion, Economic impact, Ecological impact, Coastal erosion, Economic impact studies

\section{Economic Impact of Hurricane Katrina}

After Hurricane Katrina hammered the U.S. Gulf Coast and spurred massive flooding in New Orleans, the economic and ecological impacts are still being felt throughout the region. The economic damage from Hurricane Katrina is still being tallied. While most hurricanes have economic effects, Katrina had many unique factors: its impact on the individuals living in the affected areas, the U.S. energy production; the gambling industry, the impact on agriculture and forestry, and the vast array of ecological effects. Action Economics decided to take a first pass at estimating the economic damage and how it has affected U.S. economic output. Their estimates assumed that Katrina would subtract 0.7 percentage points from growth in gross domestic product in the third quarter, lowering the expected U.S. growth rate to $3.7 \%$. Additionally, they predicted a 0.4 percentage point hit to the fourth quarter, with growth in that quarter now set at $3.9 \%$.

\section{(1) Katrina's Impact on the Individuals Living in the Affected Areas}

Hundreds of thousands of residents of southern Louisiana and Mississippi, including nearly everyone who lived in New Orleans, were left unemployed. No paychecks were being cashed, and no money was being spent; therefore no taxes were being collected by local governments. The lack of revenue has limited the resources of the affected communities and states and will do so for years to come. Productive workers lost their jobs. It will take years for most of them to recover the level of earnings (productivity) that they enjoyed; therefore the overall economy experienced a severe loss in productivity.

Before the storm, the region was already one of the poorest in America with one of the highest unemployment rates. Furthermore, Jim Sensenbrenner, Republican chairman of the House Judiciary Committee, refused to allow victims of the hurricane to take advantage of any exception to the recent Bankruptcy Reform, a recent bill passed with widespread support of the banking industry which was aimed to curb abuse of bankruptcy protection by repeat filers and those who are able to repay debts reasonably.

Area residents were also somewhat concerned when, on September 8, 2005, President Bush temporarily suspended the Davis-Bacon Act in the affected areas, which allowed for contractors working on Federal construction projects to be paid less than the prevailing local wage. The concerns over these actions were primarily that allowing the government to pay less than the prevailing wage would contribute to increased poverty in the region, which already ranked among 
the lowest in the nation in terms of household income. The act was later reinstated on October 26, 2005, amid political pressure from both Democrats and Republicans in the United States Congress.

The storm left hundreds of thousands homeless in the region, at least 100 dead in hardest--hit Mississippi alone, and homes damaged by floods and winds well inland from Tennessee to Georgia. Estimates of insured losses go as high as \$25 billion, although many experts believe the total will come in lower. More than 1,300 people in Louisiana died during Hurricane Katrina and the ensuing floods last year. And while the deaths cut across all races, it was age that appeared to determine the likelihood of survival. Nearly 40 percent of the people identified so far were over the age of 71.

\section{(2) Katrina's Impact on U.S. Energy Production}

Hurricane Katrina impacted the oil and the gas infrastructure, not just short term but long term as well. More specifically, the impact of the storm was that the Gulf was shut down; all of the affected areas of the storm were shut down; and a half billion dollars a day of oil and gas were unavailable.

The storm interrupted oil production, importation, and refining in the Gulf area, thus having a major effect on fuel prices. Before the storm, one-tenth of all the crude oil consumed in the United States and almost half of the gasoline produced in the country came from refineries in the states along the Gulf's shores. An additional $24 \%$ of the natural gas supply was extracted or imported in the region. Furthermore, the nation's Strategic Petroleum Reserve was also stored in this region.

Perhaps equally important were the power outages in the wake of Katrina which caused distribution problems for oil and natural gas. Pipelines which move petroleum products from places like Houston to areas of the east coast had their flow interrupted because of the power outages that shut down the pumps which kept materials flowing. After the storm, at least twenty offshore oil platforms were missing, sunk, or had gone adrift.

The Louisiana Offshore Oil Port, which imported 11\% of all U.S. oil consumption, closed on August 27, and Shell reported a reduction in production of 420,000 barrels per day. The port was undamaged by the storm and resumed operation within hours of getting power back.

Due to fears that the production of oil in the United States would be cut by up to one-third of normal capacity, the price of oil fluctuated greatly. In some areas, gasoline was being sold for as much as $\$ 6$ per gallon. International oil prices also rose. In the United Kingdom, pump prices for unleaded petrol (gas) hit £1 per liter (\$7 per U.S. gallon) for the first time in a significant number of places (averaging about 95p), a rise of about $3 \%$ from pre-Katrina prices. Wholesale prices were up $5 \%$ by September 6. Long lines developed at some gas stations throughout the U.S. as customers rushed to buy gasoline, anticipating price increases in the wake of the storm.

As a result of Katrina, by August 31, eight Gulf of Mexico refineries remained shut down, and one was operating at reduced capacity. Aside from the problems involved in restarting the refineries (which is a lengthy process) there were additional major issues with worker housing, since a large proportion of homes were destroyed by the hurricane.

The Environmental Protection Agency moved to reduce prices by temporarily lifting fuel standards in America until September 15. Some crude oil was also released from the Strategic Petroleum Reserve, as well, to combat prices as major economic consequences were predicted if prices remained high for a long period of time. Also consumer spending dropped and this alone caused many foreign economies, especially in Asia, to suffer. Ultimately, President Bush also temporarily waived the Jones Act, allowing foreign oil companies to ship oil between ports of the United States.

By September 7, Gulf oil production had returned to $42 \%$ of normal. Of 10 refineries that were shut down by Katrina, four were expected to be back at full capacity within a week; however another four could be out of commission for months.

\section{(3) Katrina's Impact on the Gambling Industry}

Katrina forced many casinos along the Mississippi Gulf Coast to close and evacuate. Before the storm, at least 14,000 people were employed at Gulf Coast casinos. Listed below are the specific details of major casinos which were impacted.

1) The Hard Rock Hotel \& Casino was scheduled to open the first week of September, but has remained closed indefinitely due to structural damage.

2) The Beau Rivage was severely damaged by water that reached the third floor, but seems to have suffered the least damage of the beachfront casinos.

3) Grand Casino Biloxi had its mammoth gaming barge blown across U.S. 90. Treasure Bay's pirate ship was washed ashore. 
4) The President Casino Biloxi was washed across U.S. 90 and landed on top of a Holiday Inn, nearly a mile (2 km) from the casino's berth.

5) In Gulfport, the western Grand Casino Gulfport barge, containing Kid's Quest, washed across U.S. 90 and was left blocking the highway.

6) The Copa Casino barge was pushed onto land next to the Grand Casino Gulfport's parking garage.

7) Casino Magic and Isle of Capri in Biloxi both suffered heavy damage to their gaming barges, likely beyond repair.

8) Harrah's New Orleans closed shortly before the storm and sustained storm damage. The building was also used by first responders as a base of operations in the days following the storm.

An update since the hurricane revealed that Harrah's casino reopened on February 17, 2006, just in time for Mardi Gras, and the Beau Rivage Resort and Casino in Biloxi, Mississippi, reopened on August 29, 2006, on the one year anniversary of Hurricane Katrina's landfall. The Grand Casino Biloxi is undergoing extensive renovation, and is expected to reopen during the summer of 2006. The Grand Casino Gulfport was destroyed as portions of the structure collapsed across Highway 90 and was demolished.

\section{(4) Katrina's Impact on Agriculture and Forestry}

According to the United States Department of Agriculture (USDA), the national impact of Hurricane Katrina on Gulf Coast crops was described as minimal, with most of the damage borne by minor producers of major crops (corn, soybeans, and cotton). The main impact of the storm on agriculture is likely to involve ocean shipping and exports. In 2004, 22\% of U.S. wheat exports, $71 \%$ of corn exports, and $65 \%$ of soybean exports passed through Gulf ports. However, major grain shipping usually does not occur until later in the fall, when ports would again be operational.

In addition to the 48 Mississippi counties covered by the Presidential primary natural disaster designation, the USDA declared an additional 31 counties as primary agricultural disaster areas. This made farmers and other agricultural producers eligible for low interest emergency loans to cover losses. The remaining four Mississippi counties were classified as, "contiguous" and were also eligible for assistance.

Gulfport, Mississippi serves as a major ocean shipping port for the southern United States, which was found to be inoperable for as much as one year. Chiquita, Dole, Crowley, Gearbulk, P\&O, and others had significant operations in Gulfport. On a short-term basis, these companies have relocated necessary operations to unaffected ports.

Forestry constitutes a major industry in southern Mississippi, accounting for $10 \%$ of all jobs in the state. According to the Mississippi Forestry Commission, Hurricane Katrina caused significant damage to 1.3 million acres $\left(5,300 \mathrm{~km}^{2}\right) \mathrm{of}$ forestland in the state. The greatest damage occurred from the coastal counties northward to Laurel, with heavy damage to pine forests in Hancock, Harrison, and Pearl River counties.

An estimated 14.6 million cords $\left(52,900,000 \mathrm{~m}^{3}\right)$ of paperwood and 3.2 billion board feet $\left(7,600,000 \mathrm{~m}^{3}\right)$ of sawtimber were destroyed. The estimated economic impact of this loss was $\$ 1.3$ billion. Additionally, there was an estimated \$1.1 billion in damage to urban trees in 181 Mississippi communities.

\section{(5) Katrina's impact on the ecology}

A major economic impact which is sometimes overlooked is the economic impact of the ecological damage. This research attempts to translate these damages into comparable dollars. The ecological consequences from Katrina were considerable: storm surges flooded coastal areas. Powerful winds felled forests in south Louisiana and Mississippi which were havens for wildlife and migratory birds. Saltwater and polluted floodwaters from New Orleans surged into Lake Pontchartrain. Wetland restoration plans must close or restrict the Mississippi River Gulf Outlet, a canal that contributed to the flooding of New Orleans and disconnects the river from its delta plain. Wetlands help stem storm surges and diffuse powerful winds.

The continuing effects of saltwater intrusion driven by Katrina can be still seen in the wilting trees and plants far from the coast. The inland saltwater intrusion caused the state's rice crop to decrease by 20 percent this year. The canals that connect the city to the coast allow storm surges to travel inland, bringing salt water that damages the land. An example of such a canal is the Mississippi River Gulf Outlet, which was built in the mid-1960s to be a 76-mile (122-kilometer) shortcut between the Gulf of Mexico and New Orleans. Before the record hurricane season of 2005, salt water brought inland by the canal was fingered as the culprit in the death of thousands of acres of cypress swamp, a natural buffer against storms. When Katrina hit, levee failures on the canal allowed water to pour into St. Bernard Parish and New Orleans East.

Some fields could take up to two years to recover. The rice acreage was down in southwest Louisiana by about 80,000 to 90,000 acres [32,400 to 36,400 hectares] because of the storm surge. Many plants were not planted because of soil contamination or contaminated waterways that would be used to flood the rice fields. Lake Pontchartrain is one of the few examples of quick ecological recovery following the record storm season. 
In the weeks after Katrina, polluted floodwaters dubbed the toxic stew were pumped directly from the streets of New Orleans into the lake. It was estimated by Carlton Dufrechou, an environmental engineer and executive director of the Lake Pontchartrain Basin Foundation, that about 10 billion gallons (38 billion liters) of contaminated water were dumped into Pontchartrain. One saving grace was that it was less than 10 percent of the lake's volume, therefore the bacteria counts dropped almost immediately after the pumping stopped in October.

The barrier islands that extend from Texas to Florida have historically served as the Gulf Coast's major natural protection from hurricanes. These long thin islands just off shore buffer the mainland from strong winds and ocean waves. The constant battering from intense tempests over the years has taken its toll on these islands. Hurricane winds cut Petit Bois Island from Dauphine Island 150 years ago, and in 1969 Hurricane Camille sliced Ship Island in half. Additionally, canals and levees along the Mississippi River prevent fresh sediment deposits from building the islands back up.

Louisiana's Chandeleur Islands — which have shrunk considerably in the past decade —were almost wiped off the map because of Katrina. According to Rick Clark, chief of science and resources management for the Gulf Islands National Seashore, "Katrina's towering storm surge completely washed over most of the barrier islands along the Mississippi coast, scattering hefty amounts of debris. A substantial amount of our recovery effort was just getting that inorganic debris off [Ship Island]. Some of it is still scattered; heavy equipment and all-terrain vehicles that might have ended up in a pond or an area that is just too sensitive for us to go in right now." For the future, scientists say, there are many viable solutions for restoring and protecting the coast against further storm damage.

Thick layers of sediments deposited over the coast can help create wetland sustainability, but it will become more difficult to maintain in coming years because of more frequent and more intense hurricanes. Raising public and political awareness of the threats to Louisiana's ecology is the most critical path of action.

\section{Review of Salt Water Intrusion}

When fresh water is withdrawn at a faster rate than it can be replenished, a draw down of the water table occurs with a resulting decrease in the overall hydrostatic pressure. When this happens near an ocean coastal area, salt water from the ocean intrudes into the fresh water aquifer. The result is that fresh water supplies become contaminated with salt water as is happening to communities along the Atlantic and Gulf coasts.

More specifically, saltwater intrusion is the movement of salt water into a non-salt water environment, such as a freshwater marsh. This intrusion may occur as the result of a natural process like a storm surge from a hurricane or from human activities such as construction of navigation channels or oil field canals. These channels and canals provide conduits for salt water from the Gulf of Mexico to reach deep into interior marshes.

Saltwater intrusion can be detrimental to these marshes because water with high salt concentrations can adversely affect vegetation in the marsh. For instance, when highly saline water enters a low-saline or non-saline area, most or all of the native plant life will be destroyed. Because plant root systems are essential in holding the marsh soil together, loss of plant life eventually leads to rapid erosion.

Saltwater intrusion is a natural process that occurs in virtually all coastal aquifers. It consists in salt water (from the sea) flowing inland in freshwater aquifers. This behavior is caused by the fact that sea water has a higher density (which is because it carries more solutes) than freshwater. This higher density has the effect that the pressure beneath a column of saltwater is larger than that beneath a column of the same height of freshwater. If these columns were connected at the bottom, then the pressure difference would trigger a flow from the saltwater column to the freshwater column.

The flow of saltwater inland is limited to coastal areas. Inland the freshwater column gets higher and the pressure at the bottom also gets higher. This compensates for the higher density of the saltwater column. Where this happens, saltwater intrusion stops.

The higher water levels inland have another effect: they trigger flow of freshwater seaward. This completes the picture: at the sea-land boundary, at the high part of the aquifer freshwater flows out and in the lower part, saltwater flows in. The saltwater intrusion assumes the virtual shape of a cone.

Saltwater intrusion is a natural process, but it becomes an environmental problem when excessive pumping of fresh water from an aquifer reduces the water pressure and intensifies the effect, drawing salt water into new areas.

When freshwater levels drop, saltwater intrusion can proceed inland, reaching the pumped well. Then saltwater, is unfit for drinking or irrigation. It will then be produced by the pump. To prevent this, more and more countries adopt extensive monitoring schemes and numerical models to assess how much water can be pumped without causing such effects.

The first physical formulations of saltwater intrusion were made by W. Baydon-Ghyben $(1888,1889)$ and A. Herzberg (1901), thus called the Ghyben-Herzberg formulation. They derived analytical solutions to approximate the intrusion behavior, which are based on a number of assumptions that do not hold in all field cases. The Ghyben-Herzberg ratio 
states, for every foot of fresh water in an unconfined aquifer above sea level, there will be forty feet of fresh water in the aquifer below sea level.

Over the years, many laboratory and field experiments have been conducted to estimate decreases in crop yield as a function of increasing levels of salinity in the soil root zone. Knowledge of the ability of crops to tolerate salinity and still produce a measurable agricultural product is critical to optimal management of salt-affected lands. In 2004, Harold Steppuhn, Van Genuchten and Grieve made a detailed assessment of available literature and devised a general relationship that accurately estimates crop yield in response to soil root- zone salinity. Their data indicated that product yields of agricultural crops grown subject to increasing levels of root-zone salinity decrease according to a sigmoidal-shaped response curve. Comparisons among six possible empirical response models applied to the results from a spring wheat test crop reveal that the modified compound-discount function is the most precise. This function features two parameters: the salinity level causing a 50 percent product loss, and the absolute value of the general decline in relative crop yield with salinity at and about the 50 percent yield level. Combined, these parameters form a salinity tolerance index (the ST-Index) useful in developing crop lists of tolerances to root-zone salinity.

Even so, the modeling of saltwater intrusion is considered difficult. Some typical difficulties that arise are:

- The possible presence of fissures and cracks and fractures in the aquifer, whose precise positions are unknown but which have great influence on the development of the saltwater intrusion

- The possible presence of small scale heterogeneities in the hydraulic properties of the aquifer, which are too small to be take into account by the model but which may also have great influence on the development of the saltwater intrusion

- The change of hydraulic properties by the saltwater intrusion. A mixture of saltwater and freshwater is often undersaturated with respect to calcium, triggering dissolution of calcium in the mixing zone and changing hydraulic properties.

- The process known as cation exchange, which slows the advance of a saltwater intrusion and also slows the retreat of a saltwater intrusion.

- The fact that saltwater intrusions are often not in equilibrium makes it harder to model. Aquifer dynamics tend to be slow, and it takes the intrusion cone a long time to adapt to changes in pumping schemes, rainfall, etc. So the situation in the field can be significantly different from what would be expected based on the sea level, pumping scheme etc.

- $\quad$ For long-term models, the future climate change forms a large unknown. Model results often depend strongly on sea level and recharge rate. Both are expected to change in the future.

Saltwater intrusion is also an issue where a lock separates salt water from fresh water (for example the Hiram M. Chittenden Locks). In this case a collection basin was built from which the salt water can be pumped back to the sea. Some of the intruding salt water is also pumped to the fish ladder to make it more attractive to migrating fish.

Fresh water is a scarce resource. According to the World Meteorological Organization, only 2.5 percent of the total water volume on the Earth is fresh water and the remainder is saline. The largest available source of fresh water still lies underground and the availability of surface water has become sparse in many areas in the world. Groundwater is used extensively to supplement available surface water to meet ever increasing water demand in the world. When considering the water resources in areas bordering seas, coastal aquifers are important sources of fresh water.

Use of coastal aquifers as operational reservoirs in water resource systems requires the development of tools that facilitate the prediction of the aquifer behavior under different conditions. Quantitative understanding of the patterns of movement and mixing between freshwater and saltwater, as well as the factors that influence these processes, are necessary to manage the coastal groundwater resources. It is imperative to understand these processes when planning salinity management strategies. Hence, the studies on saltwater intrusion have become necessary in designing and planning of groundwater systems in coastal areas.

In nature, the freshwater-saltwater interface seldom remains stationary. Large scale recharge into the aquifer as well as withdrawals from it will result in the movement of the freshwater-saltwater interface from one position to another. The movement will advance or retreat, depending on whether the freshwater flow through the aquifer is decreased or increased. Therefore, change in groundwater recharge directly affects the saltwater intrusion. Subsequently, saltwater intrusion of coastal aquifers will accelerate due to the reduction of groundwater recharge. This could mean a reduction of fresh groundwater resources in coastal aquifers. Even though groundwater recharge is the major source of freshwater across most aquifers, particularly in arid and semi-arid regions, there has been very little research on the potential effects of groundwater recharge on saltwater intrusion and factors affecting the saltwater intrusion. 


\section{Economic Impact of Salt Water Intrusion for Hurricane Katrina}

Economic impact studies measure direct and indirect effects on an area economy. Direct impact refers to the area's spending on goods and services, its various sources of income, and employment levels. Indirect impact is the effect of the area's spending and employment on other sectors of the economy through the multiplied impact of spending and job creation. The indirect impact is an attempt to measure the impact on various businesses and industries that depend on the re-spending of income and other expenditures generated by an area. The analysis in this research begins the creation for estimates to be used in explaining the direct effects of salt water intrusion as a result of hurricane Katrina.

Hurricanes Katrina caused tidal surges that left concerns about salt deposition in soil. The unprecedented flooding inundated almost 40,000 acres of sugarcane in the coastal parishes of Louisiana.

While a considerable acreage of sugarcane was damaged or killed by the direct effects of the flood waters, the extent of the effects on sugarcane from the salt content of sea water is not completely known.

Representatives of several state and federal agencies met in October to discuss the hurricanes and their aftermath. A decision was made to develop a soil sampling protocol to be used to survey the soils in the flood zone for salinity.

Initial sampling was limited in scope and specifically sought information on the enormity of the salt contamination problem. Seven sites across Iberia, St. Mary and Vermilion parishes were chosen for the initial round of sampling. The sites were selected on the basis of soil texture, depth and duration of the flood waters and distance from the coast.

Soil cores were taken at depths of 0-3 inches, 3-6 inches, and 6-12 inches to determine the distribution of salt within the soil profile.

The amounts of salt measured in the first samples varied widely, as anticipated. The highest concentration was found at the 0-3 inch depth, ranging from 268 to $4,329 \mathrm{ppm}$. Though salt levels decreased with depth of sampling, the saltiest site contained almost 2,000 ppm in the 6-12 inch core.

The level of salinity across sites was not predictable and did not appear to be associated with texture or any other variable.

Published reports suggest sugarcane is moderately sensitive to salt, with a saturated-extract electrical conductivity (EC) threshold for yield reduction at $1.7 \mathrm{dS} \mathrm{m}-1$ (multiplying dS m-1 times 640 equals ppm). Research in Texas measured reductions in Brix, pol and purity and increases in fiber with each dS m-1 increase in EC.

Because salt levels for most sites in the survey exceeded that of the salinity damage threshold of approximately 1,100 ppm, an additional 20 sites were sampled across a four-parish area in early November. A couple of the new sites contained levels of over $6,000 \mathrm{ppm}$ in the surface 3 inches of soil.

Twelve of the original sites were re-sampled in early February to determine whether sufficient leaching had occurred to reduce the salinity. Surprisingly, despite over 14 inches of rain at several sites, salinity levels increased at five of the 12 sites.

At the time of the February re-sampling, a majority of the sampling sites contained salt at levels which exceeded that of the damage threshold of $1,100 \mathrm{ppm}$.

Flooding of agricultural land by hurricane storm surges can have both short-term and long-term effects on both crops and soil structure. While most of the "salt" in seawater is sodium chloride (table salt), it also contains appreciable amounts of magnesium sulfate (Epson's salts) and other elements.

After heavy rains, sodium and chloride will be preferentially lost in runoff and leachate. Therefore, within the next two years, much of the agricultural land flooded by last season's storm surges should naturally recover and return to previous levels of productivity.

Recovery will occur more quickly in fields that received lower amounts of salt. A few areas that accumulated very high levels of salt are possibly at risk of becoming sodic, and may not recover without help.

The storm surge analysis offered by the LSU AgCenter's Soil Testing Lab reports both salinity (ppm) and SAR (sodium absorption ratio). Salinity (ppm) is the better indicator of the salt impact on crops; however, if the SAR is greater than 15 , the site should be carefully monitored. Not only will it take considerable time for salinity levels to drop, but the field is at risk of collapsing during the process. Water will not infiltrate a collapsed soil, the $\mathrm{pH}$ will rise above 8 , and toxic amounts of sodium will remain.

Reclaiming such soils is costly and requires addition of large amounts of gypsum plus mechanical drainage. None of the sites in their initial monitoring studies is currently in need of gypsum, but some would benefit from the addition of lime. If a field has an SAR $>15$ and low $\mathrm{pH}$, application of agricultural lime will ensure that sodium is leached and sodic conditions are avoided. Even where the SAR is $<15$, if soil $\mathrm{pH}$ is below 6.0, the addition of lime can help offset the effects of excessive salt and accelerate the leaching process. 
Monitoring of soil salt levels will continue until sugarcane harvest, at which time a yield impact assessment will be made in an attempt to confirm the applicability of the salinity damage threshold for sugarcane in Louisiana.

Preliminary estimates of the economic impact from hurricane Katrina to Louisiana agriculture were calculated as well over $\$ 1$ billion dollars (refer to table 1 in the appendix). The major contributing factors which led to these impacts were reduced revenue, lower market prices and increased production cost. The three largest commodities which were impacted were forestry $(\$ 612.9 \mathrm{M})$, agronomic crops (sugarcane, cotton and rice) $(\$ 156.1 \mathrm{M})$ and fisheries $(\$ 142.2 \mathrm{M})$. Damage estimates for forestry were developed based on forestry industry personnel's assessment of the percentage of timber affected in impacted regions and the expected Christmas tree loss. Damage estimates for sugarcane were based on personnel's assessment of production losses, increased planting and harvesting costs and revenue loss and increased costs associated with flooded cane acres. Experience with past storms has indicated that sugarcane production could be affected by 10 to 15 percent in subsequent future years because of carry-over effects including saltwater intrusion. These estimates include an estimate for the direct economic effects of salt water intrusion.

\section{A Specific Case of Salt Water Intrusion in New Orleans's City Park}

The impact of salt water intrusion on New Orleans's City Park was enormous. Katrina's floodwaters damaged 122 park buildings and submerged 90 percent of City Park in saltwater, killing the grass on the golf courses and the plants in the botanical garden. More than four feet of water in the parks administration building ruined computers, archives and records. A portion of the maintenance building collapsed and nearly every piece of equipment was destroyed. Total park damages are estimated at well over $\$ 43$ million.

Since the storm, the 1,300-acre park has reopened many of its facilities, including the golf driving range, the Botanical Garden, pavilions and tennis courts. Saltwater and muck covered the fountain and its surrounding grounds during flooding after Katrina, and a 2,700-foot ornamental iron perimeter fence sustained major damage. The Starwood-led effort included landscaping, general cleanup and fence-painting, along with a push to clear nearby limbs and debris from the banks of a nearby bayou. While the 11-acre Popp Fountain site is a minuscule slice of the 1,300-acre park between Lakeview and Bayou St. John, it holds unusual interest because of its history -- and, especially now, it's potential for generating money. In the months before Katrina, the fountain area brought in $\$ 1,750$ in rent for each private party, not including income from catering and liquor sales, and the cash-starved park is determined to open it up to private rental again in coming months.

Hurricane Katrina took down about 1,000 of the park's 14,000 trees and snapped thousands more limbs. Muck smeared roads and paths. Salty floodwater had poisoned acres of grass and thousands of plants. More than $90 \%$ of its 1,300 acres were submerged after the surge from Lake Pontchartrain spilled in from the 17th Street Canal, a mile west. Katrina derailed the park's kiddie railroad, destroyed vehicles and damaged every building. Four swans ended up in a park across town. All of the paddleboats floated away.

City Park is as integral a part of the New Orleans community as are the police, the firefighters, and the doctors. With virtually no park income, approximately $98 \%$ of the $\$ 10.8$ million annual budget came from user fees and donations. Katrina destroyed the revenue base and caused a lay off of more than $90 \%$ of the 260 -member staff. Repairs will cost well over $\$ 43$ million, much of which the Federal Emergency Management Agency may cover. Additionally the operating funds for the park will be scarce for months. City Park gets no city money and only $\$ 200,000$ a year from the state. Nominal income now includes only fees from an occasional footrace and from the tennis courts. Before Katrina, a steady parade of people found recreation and relaxation in barbecues, golf, high school football, family reunions, softball, soccer, boat rides and so many weddings that the park was the largest non-hotel caterer in town. In summary, Hurricane Katrina changed the following aspects of City Park:

1) Trees. The signature live oaks lost many limbs, but most survived. Many magnolias and pines and 150

cypress trees did not. The brackish deluge may have killed 1,000 more trees that won't show until spring.

2) Plants. The saltwater flood killed all but a fraction of the garden stock which includes 2,100 plants. The rose garden alone lost 1,658 bushes.

3) Golf. The three Bayou Oaks courses, a key revenue source and the South's largest municipal golf center, were wiped out, a \$15 million loss. They are unlikely to reopen until many more people return.

4) Amusements. Besides the wrecked mini-train, the park rides are closed, as is Storyland, a garden with fairy-tale figures. Katrina buckled the century-old carousel's floor but spared its antique carved horses. Staffers salvaged fallen cypress logs for a saw mill to cut new floorboards.

5) Other facilities. Tad Gormley Stadium, site of the 1992 U.S. Olympic track and field trials and a 1964 Beatles concert, took a \$2 million hit. The New Orleans Museum of Art suffered \$6 million in damage and had to lay off most of its staff, but all of its artworks survived. 
For now, the biggest potential income source for New Orleans's City Park is rent. Park managers hope to win FEMA approval to install up to 1,800 trailers for residents whose homes were lost. Scores of cleanup workers already pay to park RVs or to pitch tents there in the park.

\section{Summary}

Approximately $70 \%$ of the world's population lives in coastal areas. Groundwater systems in coastal areas will continue to come into contact with saline water; therefore, one of the major problems is saltwater intrusion. Saltwater intrusion will continue to replace the fresh water in coastal aquifers by saltwater due to the motion of a saltwater body into the freshwater aquifer. Saltwater intrusion will reduce the available fresh groundwater resources in coastal aquifers. At present, many coastal aquifers in the world, especially shallow ones, experience an intensive saltwater intrusion caused by both natural and human-induced processes.

Changes in climatic variables, such as precipitation and temperature, and the land-use change have significantly altered groundwater recharge rates for major aquifer systems. Under such circumstances it is important to study the problem of saltwater intrusion and to accurately estimate the saltwater intrusion due to changes in recharge or discharge of groundwater and related activities such as climate changes and change in land-use pattern.

Climate change will have profound effects on the hydrologic cycle through altered precipitation, evapotranspiration, and soil moisture patterns. Atmospheric carbon dioxide levels have continually increased since the Industrial Revolution. The continuation of this phenomenon may significantly alter global and local climate characteristics, including temperature and precipitation. Extra precipitation will continue to be unequally distributed around the globe. Some parts of the world may experience significant reductions in precipitation, or major alterations in the timing of wet and dry seasons. These changes will lead to altered groundwater recharge in watershed areas, which will change the groundwater flow to coastal regions and determine the rate of saltwater intrusion in coastal aquifers. Therefore, information on the local or regional impacts of climate change on hydrological processes and coastal water resources is becoming more important. Inclusion of these activities as a part of the management planning stage is paramount for coastal areas.

Changing land use and land management practices can also alter the hydrological system. Land-use change has a direct effect on hydrologic processes through its link with the evapotranspiration regime on one hand and the sometimes extreme change in surface runoff on the other hand. Hence, land use also plays a major role in assessing groundwater resources. Precipitation is the primary source of groundwater and varies both temporally and spatially. For most hydrological applications, it is appropriate to assume that precipitation is independent of vegetation type, and evapotranspiration and surface runoff are closely linked with land-cover characteristics. A large number of land-use impact studies on water resources have been carried out for watersheds with a focus on water scarcity, flood, erosion, and water management.

The accumulation of economic and ecological damages from hurricane Katrina is still increasing. Many effects still need to be evaluated, and only time will determine the devastation, including salt water intrusion. Future studies, which will account for the immediate and the long- term effects and as well the indirect economic effects of salt water intrusion, will become increasing more important as the dollar value for Katrina continues to mount. Modeling these economic impacts will increase our knowledge and assist planners in preparing for future variable weather patterns.

\section{References}

Bosworth, M. H. (2005). No bankruptcy relief for Katrina victims. ConsumerAffairs.com. Retrieved from http://www.consumeraffairs.com/news04/2005/katrina_bankruptcy03.html

Burton, M. L. and Hicks, M. J. (2005). Hurricane Katrina: Preliminary estimates of commercial and public sector damages. Marshall University: Center for Business and Economic Research. Retrieved from http://www.marshall.edu/cber/research/katrina/Katrina-Estimates.pdf

Bush, George W. (September 8, 2005). "Proclamation by the President: To Suspend Subchapter IV of Chapter 31 of Title 40, United States Code, Within a Limited Geographic Area in Response to the National Emergency Caused by Hurricane Katrina." White House, Washington, D.C. Retrieved from http://www.acq.osd.mil/dpap/general/docs/proclamation_katrina.pdf

Gizzard, Kent. (September 7, 2005). "Forestry Commission Reports \$2.4 billion of Tree Damage." Mississippi Forestry Commission.

Laverty, Gene. (August 28, 2005). "Oil, Gas May Soar as Storm Shuts U.S. Gulf Production." Bloomberg.

Maute, Nikki D. (September 11. 2005). "Power crews diverted: Restoring pipeline came first." Hattiesburg American.

Press Release "Harrah's New Orleans Re-Opens Friday, February 17, as the fun and excitement of Mardi Gras Begin." Harrah's Entertainment, February 6, 2006. 
Samuelson, Robert J. (September 12, 2005). "Hitting the Economy." MSNBC.

St. Onge, Jeff; Epstein, Victor. (April, 1, 2006). "Ex-chief says FEMA readiness even worse." Boston.com.

Staff Writer, (September 5, 2005). "UK petrol prices continue to rise" BBC News.

Staff Writer. (March 21, 2006). "Harrah's (Grand Casino) First Phase of Reopening", Gulf Coast Information Guide.

Staff Writer. (September 21, 2005). "Gulfport's Grand Casino Goes Bust - Literally." WLOX-TV.

Staff Writer. (September 13, 2005). "Impact on US crops from hurricane minimal, says USDA" ABC.

Staff Writer. (Accessed 2005). "Mississippi Forestry Facts", Mississippi Forestry Association.

"U.S. Census Data Three-Year-Average Median Household Income by State: 2000-2002", US Census Bureau.

Viator, H.P., G. Brietenback, J. Flanagan and all, May, 2006, "A Survey of Sugarcane Soil Content Resulting from Hurricane Katrina and Rita" LSU AgCenter.

Warner, Coleman and Travis, Robert. (October 23, 2005). "Where They Died", Times-Picayune.

Westcott, Stevin. (September 9, 2005). "USDA Designates Counties in Mississippi as Agricultural Disaster Areas" United States Department of Agriculture.

Wilmon, Tom. (August 22, 2006). "Beau Rivage reopening makes it a family affair." The Sun Herald.

\section{Appendix}

Table 1. Louisiana Agriculture Preliminary Economic Damages: the direct effects of Salt Water Intrusion (\$Million)

\begin{tabular}{|l|r|}
\hline Commodity & Est. Economic Damages \\
\hline Timber & $\$ 611$ \\
\hline Christmas Trees & 2 \\
\hline Sugar Cane & 145 \\
\hline Cotton & 10.4 \\
\hline Rice & 0.483 \\
\hline Vegetables & 2.57 \\
\hline Usuries & 19 \\
\hline Citrus & 11 \\
\hline Alligators & 3.8 \\
\hline Turtles & 5.4 \\
\hline Fisheries & 142.2 \\
\hline Total & $\mathbf{\$ 9 5 3}$ \\
\hline
\end{tabular}

